ISSN 1112-9867

Available online at

http://www.jfas.info

\title{
TRACE ELEMENTS LATERAL DISTRIBUTION AND LIMITATIONS FOR REVEGETATION IN LEAD MINE SOILS: CASE OF LAKHOUAT MINE, TUNISIA
}

\author{
H. Sahraoui ${ }^{1, *}$, R. Attia ${ }^{2}$, H. Hamrouni ${ }^{2}$ and M. Hachicha ${ }^{1}$ \\ ${ }^{1}$ Institut National de Recherche en Génie Rural Eaux et Forêts. Rue Hédi Elkarray, Elmenzah \\ IV, Tunis, Tunisie \\ ${ }^{2}$ Direction des Sols. Rue Hédi Elkarray, Elmenzah IV, Tunis, Tunisie
}

Received: 23 July 2015 / Accepted: 30 November 2015 / Published online: 01 January 2016

\begin{abstract}
Anthropogenic activities such as mining have increased the prevalence and occurrence of trace elements soil contamination. Abandoned mine tailings cause the contamination of adjacent agricultural soils. In Lakhouat mining area (West-Northern Tunisia), the dispersion of particles containing $\mathrm{Pb}, \mathrm{Zn}$ and $\mathrm{Cd}$ results in the contamination of the surrounding agricultural soils. These soils presented high concentrations of $\mathrm{Pb}\left(1272 \mathrm{mg} \mathrm{kg}^{-1}\right), \mathrm{Zn}(5543$ $\left.\mathrm{mg} \mathrm{kg}^{-1}\right)$ and $\mathrm{Cd}\left(25 \mathrm{mg} \mathrm{kg}^{-1}\right)$. Furthermore, the tailing sample and soil sample close the dam tailing presented higher concentrations of $\mathrm{Pb}, \mathrm{Zn}$ and $\mathrm{Cd}$ and conferred more limitation factors for revegetation than adjacent soils of mining area. The main limiting factors of mine soils are their low effective depth, low organic matter content and low phosphorus content and an imbalance between potassium and manganese exchangeable cations. These mine soils are strongly affected by high $\mathrm{Pb}, \mathrm{Zn}$ and $\mathrm{Cd}$ levels which hinder revegetation.
\end{abstract}

Keywords: Tailing dam; Mine soils; Soil limiting factors; Trace elements; Soil contamination.

Author Correspondence, e-mail: hamdi.sahraoui@gmail.com

doi: http://dx.doi.org/10.4314/jfas.v8i1.8

\section{INTRODUCTION}

Trace elements have become increasingly important in environmental media because they are potentially toxic to plants, animals and human health. At high concentrations, trace elements 
are potentially toxic to humans and environment [1,2]. High concentrations of trace elements can be found in soils as a result of natural geochemical processes, but human activities can significantly accelerate these processes. The toxicity and the mobility of trace elements in soils depend not only on the total concentration, but also on environmental factors and soil physical and chemical properties $[3,4,5]$.

Mining activities produce a large amount of tailings and represent an important source of pollution of trace elements [5,6]. After closure of the mine and the processing facilities the mine-spoils and ore processing wastes persist, representing a source of potentially toxic elements in the environment [7].

Many cases of trace elements soil contamination have been described in former mining areas, where significant levels of various elements were mobilized by weathering and leaching from abandoned mining tailings $[8,9,10]$. Tailings from former mines are generally deposited on the soil surface located in agricultural regions. Dispersion of metal rich-particles from mine tailings is an important hazard for the adjacent agricultural soils. Furthermore, in semi-arid areas, the dispersion of fine-grained particles of tailings is often enhanced due to the natural spread of wastes by wind, scarcely soil vegetated, water and rainfall $[11,12,13]$.

Areas affected by mining activities typically support a sparse natural vegetation cover, principally as a result of an elevated concentration of trace elements combined with adverse growth conditions (such as low $\mathrm{pH}$ values, low organic matter and nutrients).

May studies have focused on revegetation due to plants potential in the rehabilitation of metal-contaminated land by removal of trace elements from the soil through their uptake and accumulation. Furthermore, revegetation aims to establish a vegetation cover and promote in situ inactivation of trace elements. This technique can potentially restore soil quality and functions, leading to the recovery of vital biogeochemical cycles.

A limiting factor is any critical soil characteristic that limits soil functions [14,15]. Factors include physical and chemical properties as texture, slope and effective depth of soil and nutrients levels. An understanding of the different limiting factors of vegetation is essential in establishing and maintaining plant cover on the affected zone when carrying out stabilization and restoration work [16].

The objectives of this study were to characterize the mine soils from an abandoned lead mine in Lakhouat (West-Northern Tunisia) and to determine the soil limiting factors for revegetation. 


\section{MATERIAL AND METHODS}

\subsection{Study area}

The Lakhouat mine located in West-Northern Tunisia (UTM Zone 32 North 522005.378/ 4014334.773) (Figure 1) is characterized by a sub-humid to semi-arid climate. The heavy rainy season occurs from September to April. The most rainfall month is January with 64.9 $\mathrm{mm}$ and the driest month is July with $2.5 \mathrm{~mm}$. The highest temperature was recorded on July with $29.2{ }^{\circ} \mathrm{C}$ and lowest was recorded on January with $10.4{ }^{\circ} \mathrm{C}$. The monthly average humidity ranges from $69 \%$ in January to $41.5 \%$ in July. The prevalent winds in Lakhouat Mine are from North-East to South-West and have an average speed of $2.85 \mathrm{~m} / \mathrm{s}$. In the Lakhouat Mine, ore deposits contained galena, schalenblende, pyrite, marcasite and calcite. The tailings from the Lakhouat mine are stored on three dams (Figure 1). The adjacent soils are occupied by various annual crops essentially cereal. The mine was closed in 1992 due to the depletion of reserves.

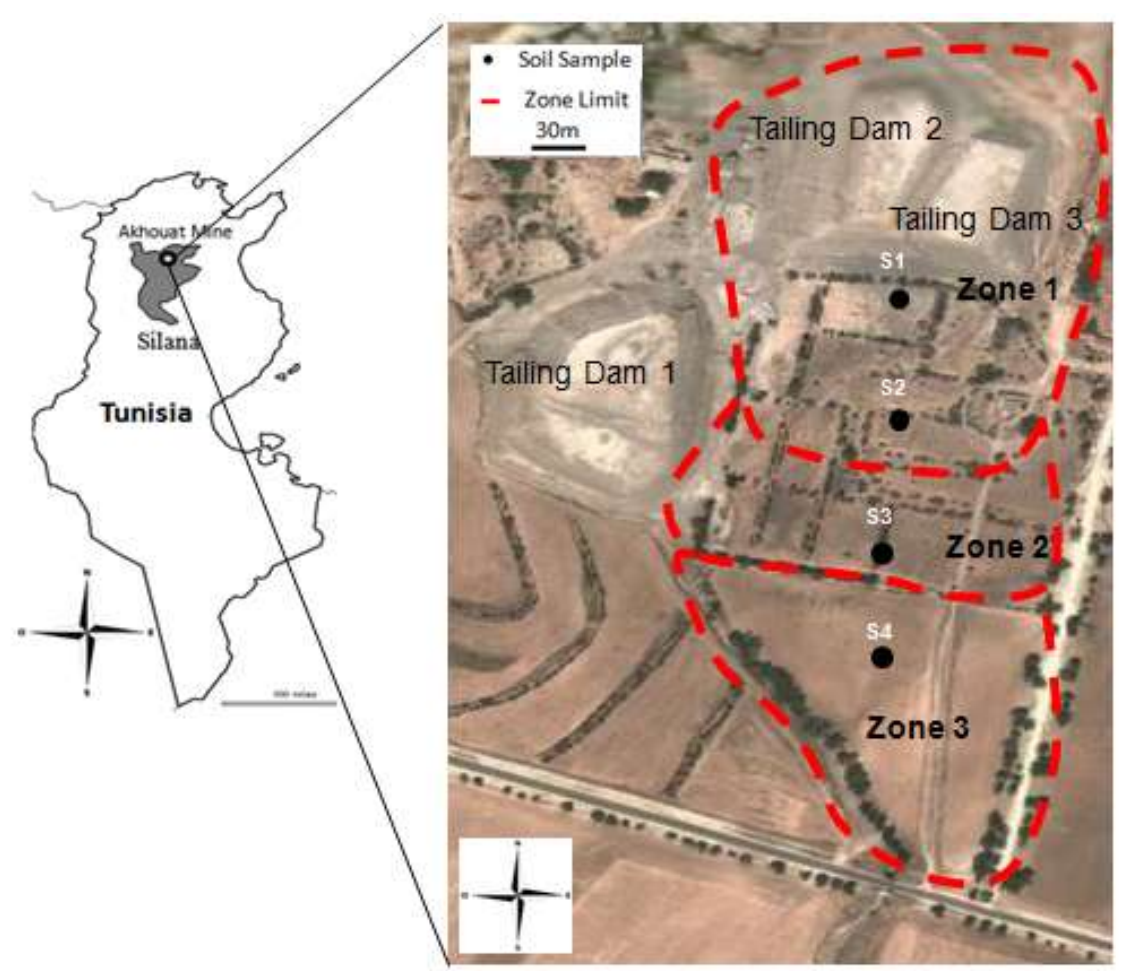

Fig.1. Location of sampling areas (S1, S2, S3 and S4) in Akhouat Mine. (Google maps)

\subsection{Soil sampling and analysis}

The study area was divided into four differentiated zones (Figure 1): (1) the mining area (2) three tailing dams where the sludge was deposited from the $\mathrm{Zn}$ and $\mathrm{Pb}$ flotation Process (3) an area close to the dams and consists of rolling hills and small riparian which make a water 
erosion evidences and (4) a zone of cereal crop plots.

A tailings sample (S1) and three soil samples (S2, S3 and S4) were taken respectively from zones 2, 3 and 4 (Figure 1), to study the lateral distribution of $\mathrm{Pb}, \mathrm{Zn}$ and $\mathrm{Cd}$.

Five subsamples per sampling area were randomly collected to a depth of $30 \mathrm{~cm}$ and stored in polyethylene bags. Soil samples were air dried in the laboratory, passed through a 2-mm sieve and homogenized in a vibratory homogeniser for solid samples.

The soils were described according to the FAO guidelines [17]. Soil $\mathrm{pH}$ was determined with a $\mathrm{pH}$ electrode (Sen Tix 41 (WTW) PLUS) in 1:2.5 distilled water to soil extracts [18]. Electrical conductivity (EC) was also determined from saturated soil-paste with Tetra 325 electrode (WTW) according to U.S. Salinity Laboratory Staff [19]. Particle size distribution was determined following oxidation of organic matter with hydrogen peroxide, the upper fraction (down to $50 \mathrm{~mm}$ ) being separated by sieving and the lower one used for subjection to the internationally endorsed procedure [20]. The effective cation exchange capacity (CECe) of the soil and exchangeable cations $\left(\mathrm{Ca}^{2+}, \mathrm{Mg}^{2+}, \mathrm{K}^{+}\right.$and $\left.\mathrm{Na}^{+}\right)$were determined by inductively coupled plasma-atomic emission spectrometry (ICP-OES) (Optima 4300 DV, Perkin-Elmer, Germany) after extraction with $0.1 \mathrm{~mol} \mathrm{~L}^{-1} \mathrm{BaCl}_{2}$ [21]. Organic matter (OM) content was determined by soil oxidation with potassium dichromate $\left(\mathrm{K}_{2} \mathrm{Cr}_{2} \mathrm{O}_{2}\right)$ and concentrated $\mathrm{H}_{2} \mathrm{SO}_{4}$ [22]. Total Kjeldahl-N (organic plus ammonium-N) was determined after sample pretreatment with salicylic acid and digestion in sulfuric acid for $20 \mathrm{~min}$. An aliquot of each extract was analyzed by potentiometric titration [23]. The phosphorus content (P) was extracted with a mixture of ammonium fluoride $\left(\mathrm{NH}_{4} \mathrm{~F}\right)$ and EDTA [24]. The carbonate content was determined with a LECO-100 analyzer connected to a LECO- CN-2000.

Total trace element content was extracted by means of acid digestion using a mixture of concentrated nitric, hydrochloric and hydrofluoric acids $(1: 3: 3 \mathrm{v} / \mathrm{v} / \mathrm{v})$ in Teflon bombs placed in a hot plate. Trace element analysis was carried out by ICP-OES (Perkin Elmer Optima 4300DV) [25].

For each physico-chemical parameter some critical values were assigned, following the modified method proposed by the Soil Fertility Capability Classification [5] (Sánchez et al., 2003) and soil quality indicators $[4,26]$. The intrinsic limiting factors for each soil sample were determined by using these criteria.

\subsection{Statistical analysis}

The results were analyzed statistically using the software SPSS ${ }^{\circledR}$ for Windows version 20.0. Statistical significance of differences was determined by variance analysis ANOVA and 
Duncan's multiple range test were used to compare the differences between the soils and the least-significant difference (LSD) test at the 5\%level was used to separate the means.

\section{RESULTS AND DISCUSSION}

\subsection{General characteristics of soils}

The topsoil description was described according to the FAO guidelines [19] (Table 1). The physical and chemical characteristics of the soils (S1, S2, S3 and S4) are summarized in table 2, which indicates significant differences in the components and properties of the soils.

The soil $\mathrm{pH}$ were alkaline and varies between 8.01 (S2) and 8.49 (S4). The organic matter content varies between $1.26 \%(\mathrm{~S} 1)$ and $1.74 \%(\mathrm{~S} 4)$. EC ranges from $0.24 \mathrm{dS} \mathrm{m}^{-1}$ (S3 and S4) to $1.10 \mathrm{dS} \mathrm{m}^{-1}$ (S1). The CECe varies between $16.91 \mathrm{cmol} \mathrm{kg}^{-1}$ (S1) and $29.37 \mathrm{cmol} \mathrm{kg}^{-1}$ (S3). Carbonate contents were not detected on $\mathrm{S} 1$ and reached $42 \%$ on $\mathrm{S} 2$. The particle size distribution of soils exhibits a substantial variation in sand, silt, and clay contents ranging from 16 to $89 \%$ for sand, 6 to $38 \%$ for silt, and $6 \%$ to $70 \%$ for clay. The soils present a nitrogen content that varies between $0.18 \%(\mathrm{~S} 1)$ to $90 \%$ (S4).

In general, $\mathrm{Pb}, \mathrm{Zn}$ and $\mathrm{Cd}$ showed very high concentrations in all samples (concentrations reached 2524, 37723 and $27 \mathrm{mg} \mathrm{kg}^{-1}$ for $\mathrm{Pb}, \mathrm{Zn}$ and $\mathrm{Cd}$ respectively). The lateral variation of $\mathrm{Pb}, \mathrm{Zn}$ and $\mathrm{Cd}$ from the tailing dam showed a decrease from the upstream to downstream (From zone 2 to zone 4 (Figure 1).

Table 1. Topsoil description of the study area

\section{S2 (Zone 3)}

0-30 cm: gray (7.5Y 5/1). Sandy texture. Weak, crumbly structure. Very friable. Adherent and plastic. Presence of very fine particles of bright color. Presence of shell debris. Presence of limestone pebbles. High porosity. Effervescence with HCl. Few roots.

\section{S3 (Zone 3)}

0-30 cm: black brown (10Y 3/2). Clayey. Weak. Crumbly structure. Friable. Adherent, and slightly plastic. High porosity. Frequent presence of roots. Effervescence with $\mathrm{HCl}$. Abundance of fine roots.

\section{S4 (Zone 4)}

0-30 cm: dark brown (7.5YR 3/3). Silty clay texture. Crumbly structure. Friable. Adherent, and slightly plastic. Presence of limestone pebbles. High porosity. Frequent presence of roots. Effervescence with $\mathrm{HCl}$. Numerous roots.

Indeed, $\mathrm{Pb}$ and $\mathrm{Cd}$ presented the highest concentrations on $\mathrm{S} 1\left(2524 \mathrm{mg} \mathrm{kg}^{-1}\right.$ for $\mathrm{Pb}$ and 27 
$\mathrm{mg} \mathrm{kg}^{-1}$ for $\mathrm{Cd}$ ). These concentrations remained high enough up, eventually for S3 which presented significant high concentrations than S2. For Zn, S3 presented the highest concentrations (37723 $\mathrm{mg} \mathrm{kg}^{-1}$ ) and showed significant difference with S1 and S2. Eventually, $\mathrm{S} 3$ showed the higher concentrations of $\mathrm{Zn}$ and $\mathrm{Pb}$ than $\mathrm{S} 2$, which has the highest content of clay (70\%), highest CECe (29.37 $\left.\mathrm{cmol} \mathrm{kg}^{-1}\right)$, moderate OM content (1.61\%) and high carbonate contents (30\%) (Table 2). Therefore, a possible explanation for this result might be that soil $\mathrm{CECe}$, clay content, carbonate and $\mathrm{OM}$ were the controlling key factors of $\mathrm{Pb}, \mathrm{Zn}$ and $\mathrm{Cd}$ soil concentration [27].

On cereal crop area (Figure 1, zone 4), $\mathrm{Pb}, \mathrm{Zn}$ and $\mathrm{Cd}$ concentrations decreased significantly to close cereal plots and reached $1272 \mathrm{mg} \mathrm{kg}^{-1}$ for $\mathrm{Pb}, 5543 \mathrm{mg} \mathrm{kg}^{-1}$ for $\mathrm{Zn}$ and $25 \mathrm{mg} \mathrm{kg}^{-1}$ for $\mathrm{Cd}$. These trace elements accumulate in agricultural soils (S4, zone 4) and vegetation, which is a health risk to humans and grazing animals.

Table 2. Physicochemical characteristics of the soil samples in the sampling areas

\begin{tabular}{|c|c|c|c|c|}
\hline Soil characteristic ${ }^{\text {a) }}$ & S1 & S2 & S3 & S4 \\
\hline $\mathrm{pH}\left(\mathrm{H}_{2} \mathrm{O}\right)$ & $8.35 b^{a)}$ & $8.01 \mathrm{c}$ & $8.16 \mathrm{c}$ & $8.49 \mathrm{a}$ \\
\hline $\mathrm{EC}\left(\mathrm{dS} \mathrm{m}^{-1}\right)$ & $1.10 \mathrm{a}$ & $0.50 \mathrm{~b}$ & $0.24 b$ & $0.24 b$ \\
\hline Sand $(\%)$ & $88 \mathrm{a}$ & $89 a$ & $16 \mathrm{c}$ & $23 b$ \\
\hline Silt (\%) & $6 c$ & $8 \mathrm{c}$ & $11 b$ & $38 \mathrm{a}$ \\
\hline Clay $(\%)$ & $6 c$ & $2 d$ & $70 \mathrm{a}$ & $38 b$ \\
\hline $\mathrm{Ca}^{2+}\left(\mathrm{cmol} \mathrm{kg}^{-1}\right)$ & $5.41 \mathrm{a}$ & $3.08 \mathrm{c}$ & $3.12 \mathrm{c}$ & $4.21 \mathrm{~b}$ \\
\hline $\mathrm{Na}^{+}\left(\mathrm{cmol} \mathrm{kg}^{-1}\right)$ & $0.61 b$ & $0.12 \mathrm{c}$ & $0.53 b$ & $3.52 \mathrm{a}$ \\
\hline $\mathrm{Mg}^{2+}\left(\mathrm{cmol} \mathrm{kg}^{-1}\right)$ & $6.64 a$ & $4.23 \mathrm{c}$ & $3.29 d$ & $4.93 b$ \\
\hline $\mathrm{K}^{+}\left(\mathrm{cmol} \mathrm{kg}^{-1}\right)$ & $3.52 \mathrm{~d}$ & $12.31 \mathrm{~b}$ & $22.43 \mathrm{a}$ & $6.24 \mathrm{c}$ \\
\hline $\mathrm{Al}^{3+}\left(\mathrm{cmol} \mathrm{kg}^{-1}\right)$ & $\mathrm{nd}^{\mathrm{b})}$ & $\mathrm{Nd}$ & nd & $\mathrm{Nd}$ \\
\hline CECe $\left(\mathrm{cmol} \mathrm{kg}^{-1}\right)$ & $16.91 d$ & $19.75 b$ & $29.37 \mathrm{a}$ & $17.62 \mathrm{c}$ \\
\hline OM (\%) & $1.26 \mathrm{~b}$ & $1.28 \mathrm{~b}$ & $1.61 \mathrm{a}$ & $1.74 \mathrm{a}$ \\
\hline Carbonate contents $(\%)$ & nd & $42 \mathrm{a}$ & $30 b$ & $24 \mathrm{c}$ \\
\hline $\mathrm{N}(\%)$ & $0.18 \mathrm{~b}$ & $0.22 b$ & $0.82 \mathrm{a}$ & $0.90 \mathrm{a}$ \\
\hline $\mathrm{P}\left(\mathrm{mg} \mathrm{kg}^{-1}\right)$ & $10.24 d$ & $13.56 \mathrm{c}$ & $28.43 \mathrm{a}$ & $20.44 b$ \\
\hline $\mathrm{Pb}\left(\mathrm{mg} \mathrm{kg}^{-1}\right)$ & 2524 & 1355 & 1860 & 1272 \\
\hline $\mathrm{Zn}\left(\mathrm{mg} \mathrm{kg}^{-1}\right)$ & 18133 & 14320 & 37723 & 5543 \\
\hline $\mathrm{Cd}\left(\mathrm{mg} \mathrm{kg}^{-1}\right)$ & 27 & 22 & 26 & 25 \\
\hline
\end{tabular}

a) Means followed by the same letter(s) within each row are not significantly different at $\mathrm{P}<0.05(\mathrm{n}=5)$. b) Not detectable. 
Similar studies in Tunisia, reported high $\mathrm{Pb}, \mathrm{Zn}$ and $\mathrm{Cd}$ concentrations in topsoil close mining sites, eventually on Bougrine, Boujaber and Fedj Lehdoum, Jalta sites reaching $12000 \mathrm{mg} \mathrm{kg}{ }^{-}$ 1, $1000 \mathrm{mg} \mathrm{kg}^{-1}$ and $19 \mathrm{mg} \mathrm{kg}^{-1} \mathrm{~Pb}, \mathrm{Zn}$ and $\mathrm{Cd}$, respectively [13,28].

High trace elements concentrations were also found on similar soil properties and similar climate. For example, In Morocco, Iavazzo et al. [29,30] reported high $\mathrm{Pb}, \mathrm{Zn}$ and $\mathrm{Cd}$ contents reaching respectively $13300 \mathrm{mg} \mathrm{kg}^{-1}, 182000 \mathrm{mg} \mathrm{kg}^{-1}$ and $1020 \mathrm{mg} \mathrm{kg}^{-1}$, in the abandoned mine of Upper Moulouya lead district site. In Spain, Monterroso et al. [2] showed a high heterogeneity lateral distribution and founded higher concentration of trace elements on mine soils than those of Tunisian mine soils, reaching $6100 \mathrm{mg} \mathrm{kg}^{-1}, 52000 \mathrm{mg} \mathrm{kg}^{-1}$ and 95 $\mathrm{mg} \mathrm{kg}^{-1}$ for $\mathrm{Pb}, \mathrm{Zn}$ and $\mathrm{Cd}$ respectively.

Three factors may be suggested to explain the lateral distribution of $\mathrm{Pb}, \mathrm{Zn}$ and $\mathrm{Cd}$ from the mine area:

(1) The topography of the region and the locations of soil samples relative to the tailing dam and the stream: The topography played an important role in the distribution of $\mathrm{Pb}, \mathrm{Zn}$ and $\mathrm{Cd}$ downstream Lakhouat tailing dam. Indeed, the region has a relatively flat topography and depressions on zone 3, that trap sediment discharges and then transported mainly by the river. These depressed areas have allowed the deposit of tailing wastes, for this reason S3 showed higher significant concentrations of $\mathrm{Pb}, \mathrm{Zn}$ and $\mathrm{Cd}$ than $\mathrm{S} 2$.

(2) Physicochemical properties of soil samples: It was reported that the physical and chemical properties of soil, including $\mathrm{CECe}$, clay content, and $\mathrm{pH}$, were the dominating factors of trace elements mobility $[1,31,32]$. Lead, Zn and Cd mobility increased with decreasing soil CECe, decreasing soil organic matter decreasing carbonate contents and decreasing soil clay content [33]. Table 2 showed that the CECe content in $\mathrm{S} 3$ was $26.17 \mathrm{cmol} \mathrm{kg}^{-1}$ greater than that on $\mathrm{S} 1$ and $\mathrm{S} 2$, respectively.

(3) The abandoned tailing dams without implementing a protection system, the natural spread of tailing by wind, water and rainfall results in the contamination of adjacent soils: Wind transport of tailings may be another important factor influencing the spreading of pollution, as has been reported by several authors for pollution distribution from minning area $[13,34,35$, 36,37]. Furthermore, in semi arid environments, aeolian erosion is the dominant natural means of pollution by tailing mine spread to agricultural adjacent soils. Consequently, soils located in the prevalent wind direction from the tailing dams, were contaminated in $\mathrm{Pb}, \mathrm{Zn}$ and $\mathrm{Cd}$ due to the aeolian deposition of trace elements-rich particles. In addition, hydric transport is a local cause of trace elements contamination. For example, soils are flooded 
during flood periods and receive substantial quantities of tailings materials from tailing dams, which lead to $\mathrm{Pb}, \mathrm{Zn}$ and $\mathrm{Cd}$ contamination of the surrounding agriculture soils.

\subsection{Limiting Factors for revegetation}

A series of critical values were assigned to each of the physical or chemical parameters based on the method proposed by the Soil Fertility Capability Classification [5]

Table 3 presented the limiting factors for revegetation for S1, S2, S3 and S4. The effective depth (E.D) of S1 and S2 is less than $50 \mathrm{~cm}$, which is considered to be a limiting factor for plant growth [4]. Similarly, S1 and S2 have strong limitation for $>2 \mathrm{~mm}$ fraction and low organic matter. These conditions are often identified as some of the main factors contributing to declining soil productivity in mine soils and soil degradation by decreased aggregate stability, increased risk of erosion and reduced nutrient leaching.

The studied soils presented a moderately alkaline $\mathrm{pH}$ which contributed to a decrease of $\mathrm{Pb}$, $\mathrm{Zn}$ and $\mathrm{Cd}$ mobility essentially by the formation of precipitates and by increasing the number of sorption sites. The carbonate rich conditions at Lakhouat mine (S2, S3 and S4) produce and maintain a moderately alkaline soil $\mathrm{pH}$. This $\mathrm{pH}$ decreases the solubility of $\mathrm{Pb}, \mathrm{Zn}$ and $\mathrm{Cd}$ by reducing their soil solution concentrations and their absorption by plants.

A common chemical characteristic limit of the soils is abnormally high soil potassium which causes reduced crop production. All of the soils have a limiting factor for the studied trace elements with high concentrations of total $\mathrm{Pb}(\mathrm{pb} 1), \mathrm{Zn}(\mathrm{zn} 1)$ and $\mathrm{Cd}$ (cd1) which may seriously jeopardize the revegetation.

The limit factor $\mathrm{K} / \mathrm{Mg}$ ratio indicates that the soil has lower availability of $\mathrm{Mg}$ in all studied soil.

Soil phosphorus on S1 and S2 was low because the soil fines fraction was also low $(6 \%$ and $2 \%$ compared to $70 \%$ and $38 \%$ on S3 and S4) [38], causing less phosphorus to be available to plants [39]. In addition, decreased of the phosphorus concentrations in both S1 and S2 are probably due to organic matter adsorbing extractable phosphorus or to microbial uptake of available phosphorus for organic matter decomposition.

None of the soil samples exhibited the limit factor N, despite S1 and S2 have a low N content which might due to the toxicity of the tailings and thus the absence of microorganisms that transform organic $\mathrm{N}$ into forms that are available to plants [40]. However, we showed a progressive increase of $\mathrm{N}$ far to the lead tailing dams; eventually S3 and S4 presented higher $\mathrm{N}$ percentage indicating higher microorganism densities in these soils proportionally with the decrease of mine tailing. 
Table 3. Limiting factors for forest production in the soil samples of the sampling areas S1, S2, S3 and S4

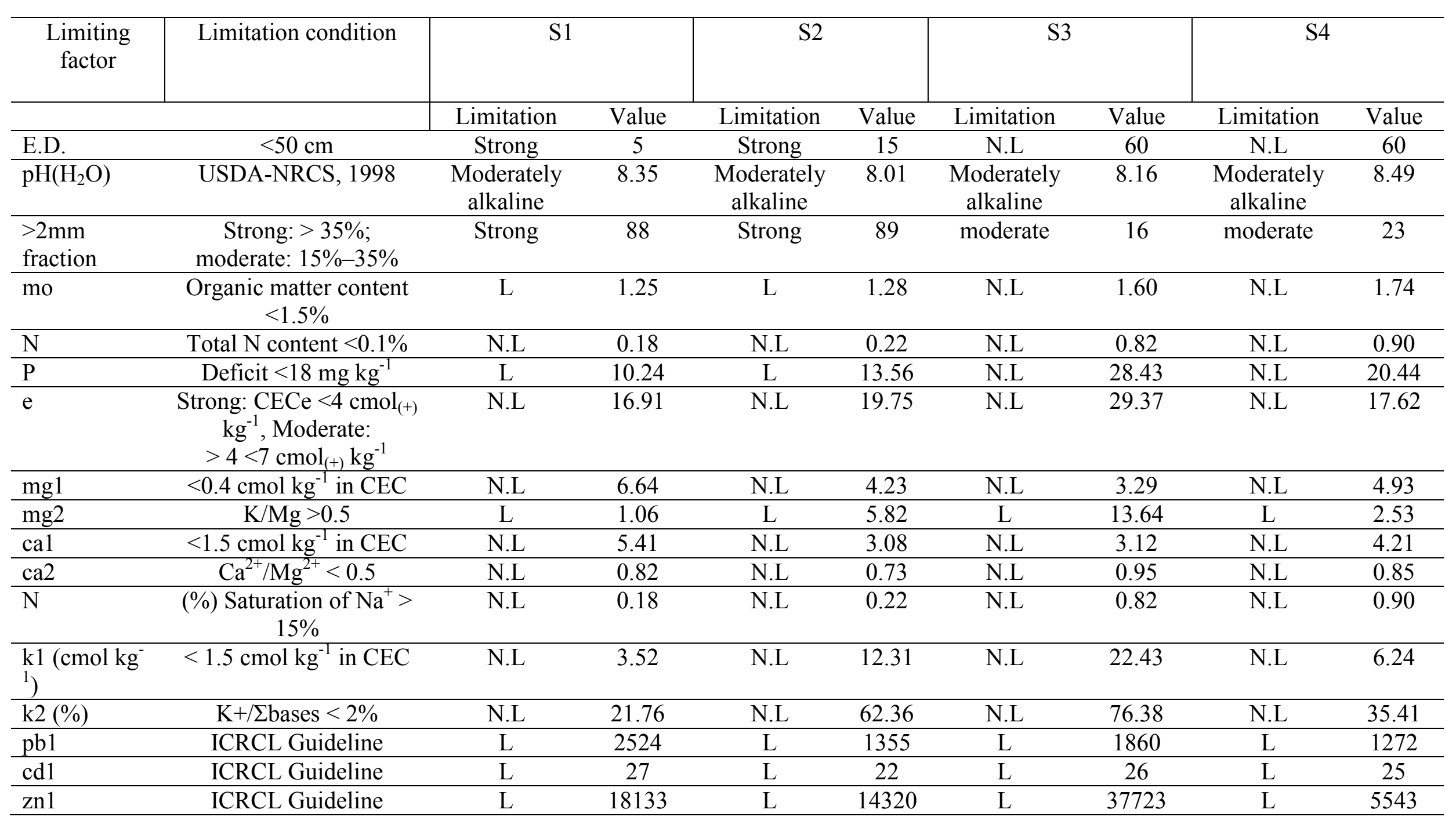


The $\mathrm{Pb}, \mathrm{Zn}$ and $\mathrm{Cd}$ concentrations of the soils is high and thus surpasses the critical limit indicated in diverse reference guides (ICRCL) [40]. Consequently, these soils are rather difficult to revegetate and then the stabilization of tailings can be very complex and slow due to trace elements toxicity. The results are consistent with those of several authors in other mine soils in Tunisia (Sidi Bouaouane, Jebel Ressas, Boujaber, Slata, Fedj Lehdoum et Bougrine) $[13,28,36,41]$ and showed that Tunisian minesoils concentrations therefore have very high $\mathrm{Pb}$ and $\mathrm{Zn}$ levels which are probably the most important hindrance that has to be overcome before revegetating [42].

\section{CONCLUSION}

The $\mathrm{Pb}, \mathrm{Zn}$ and $\mathrm{Cd}$ concentrations in the studied polluted soils were higher than the maximum limits established in some reference guides. Soil physicochemical characteristics and environmental conditions, inducing aeolian deposition of trace elements-rich particles and hydric transport from tailing dams, may influenced the lateral distribution of $\mathrm{Pb}, \mathrm{Zn}$ and $\mathrm{Cd}$ into their surroundings. The most important limitation factors of mine soils are their low effective depth, low organic matter content and low phosphorus content and an imbalance between exchangeable cations. Adding organic amendments like technosols, compost, and fertilizers can improve the soil properties; improve soil functions and quality, and benefitting the natural plant cover.

\section{REFERENCES}

[1] Alloway B.J. Environmental Pollution: Heavy Metals in Soils: Trace Metals and Metalloids. 2013, (3rd ed).

[2] Monterroso C., Rodríguez F., Chaves R., Diez J., Becerra-Castro C., Kidd P.S., Macías F. Heavy metal distribution in mine-soils and plants growing in a $\mathrm{Pb} / \mathrm{Zn}$-mining area in NW Spain. 2014, Appl Geochem. 44: 3-11.

[3] Nyamangara J. Use of sequential extraction to evaluate zinc and copper in a soil amended with sewage sludge and inorganic metal salts. 1998, Agri. Ecosyst. Environ. 69: 135-141.

[4] Schoenholtz S.H. A review of chemical and physical properties as indicators of forest soil quality: challenges and opportunities. 2000, Forest. Ecol. Manag. 138: 335-356.

[5] Passariello B., Giuliano V., Quaresima S., Barbaro M., Caroli S., Forte G., Carelli G., Iavicoli I. Evaluation of the environmental contamination at an abandoned mining site. 2002, 
Microchem. J. 73: 245-250.

[6] Bhattacharya A., Routh J., Jacks G., Bhattacharya P., Morth M. Environmental assessment of abandoned mine tailings in Adak, Vasterbotten district (northern Sweden). 2006, Appl. Geochem. 21: 1760-1780.

[7] Khorasanipour A.M., Majid H., Tangestani A., Reza N.B., Hajmohammadi H. Hydrochemistry, mineralogy and chemical fractionation of mine and processing wastes associated with porphyry copper mines: a case study from the Sarcheshmeh mine, SE Iran. 2011, Appl. Geochem. 26: 714-730.

[8] Hamilton E.I. Environmental variables in a holistic evaluation of land contaminated by historic mine wastes: a study of multi-element mine wastes in West Devon, England using arsenic as an element of potential concern to human health. 2000, Sci. Total. Environ. 249: $171-221$.

[9] Oyarzún J., Castillo D., Maturana H., Kretschmer N., Soto G., Amezaga J.M., Rötting T.S., Younger P.L., Oyarzún R. Abandoned tailings deposits, acid drainage and alluvial sediments geochemistry, in the arid Elqui River Basin, North-Central Chile. 2012, J. Geochem. Explor. 115: 47-58.

[10] Anjos C., Magalhães M.C.F., Abreu M.M. Metal (Al, Mn, Pb and Zn) soils extractable reagents for available fraction assessment: Comparison using plants, and dry and moist soils from the Braçal abandoned lead mine area, Portugal. 2012, J. Geochem. Explor. 113: 45-55.

[11] Chopin E.I.B., Marin B., Mkoungafoko R., Rigaux A., Hopgood M.J., Delannoy E., Cancès B., Laurain M. Factors affecting distribution and mobility of trace elements, $\mathrm{Cu}, \mathrm{Pb}$, $\mathrm{Zn}$ in a perennial grapevine (Vitis vinifera L) in the Champagne region of France. 2008, Environ. Pollut. 156: 1092-1098.

[12] Navarro M.C., Perez-Sirvent C., Martinez-Sanchez M.J., Vidal J., Tovar P.J., Bech J. Abandoned mine sites as a source of contamination by heavy metals: a case study in a semiarid zone. 2008, J. Geochem. Explor. 96: 183-193.

[13] Boussen S., Soubrand M., Bril H., Ouerfelli K., Abdeljaouad S. Transfer of lead, zinc and cadmium from mine tailings to wheat (Triticum aestivum) in carbonated Mediterranean (Northern Tunisia) soils. 2013, Geoderma. 192: 227-236.

[14] Doran J.W., Parkin T.B. Defining and assessing soil quality. In: Doran JC, Coleman DC, Bezdicek DF, Stewart B.A. (Eds). Defining Soil Quality for a Sustainable Environment. S.S.S.A. Special Publication. 1994, Madison WI. (pp. 3-21). USA.

[15] Doran J.W., Parkin T.B. Quantitive indicators of soil quality: a minimum data set. In: 
Doran JW, Jones AJ (Eds.) Methods for Assessing Soil Quality. S.S.S.A. Special Publication. 1996, Madison WI. (pp. 25-37). USA.

[16] Rodríguez-Seijo A., Arenas-Lago D., Lago-Vila M., Vega F.A., Andrade M.L. Limitations for revegetation in lead/zinc minesoils (NW Spain). 2014, J. Soils. Sediments. 14:785-793.

[17] FAO. Guidelines for soil description. 2006, Food and Agriculture Organization of the United Nations, Rome.

[18] Guitian F., Carballas, T. Técnicas de Análisis de Suelos. (In Spanish). 1976, Ed. Pico Sacro, Santiago de Compostela, Spain.

[19] US Salinity Laboratory Staff. Diagnosis and improvement of saline and alkaline soils, USDA Handbook 60. U.S. Government Printing Office (pp. 1-160) 1954, Washington DC, USA.

[20] Kroetsch D., Wang C. Particle size distribution. In: Carter MR, Gregorich EG. Soil Sampling and Methods of Analysis (2nd ed.). 2008, Canadian Society of Soil Science, CRC Press, Boca Raton, FL. (pp. 713-726).

[21] Hendershot W.H., Duquette M. A simple barium chloride method for determining cation exchange capacity and exchangeable cations. 1986, Soil. Sci. Soc. Am. J. 50: 605-608. [22] Walkley A., Black I.A. An examination of Degtjareff method for determining soil organic matter and a proposed modification of the chromic titration method. 1934, Soil. Science. 34: 29-38.

[23] Bremmer J.M., Mulvaney C.S. Nitrogen-total. In Methods of Soil Analysis, Part 2. (2nd ed). Agronomy Monographs, Page AL, Miller RH, Keeney DR (eds). 1982, American Society of Agronomy and Soil Science Society of America: Madison WI. 9: 595-624.

[24] Mehlich A. Soil test extractant: a modification of extractant. Commun. 1984, Soil. Sci. Plant. Anal. 15(12):1409-1416.

[25] Marcet P., Andrade M.L., Montero M.J. Efficacité d'une méthode de digestion par microondes pour la détermination de $\mathrm{Fe}, \mathrm{Mn}, \mathrm{Zn}, \mathrm{Cu}, \mathrm{Pb}, \mathrm{Cr}, \mathrm{Al}$ et $\mathrm{Cd}$ en sédiments (In Frensh). 1997, In: R. Prost (Ed.), Contaminated Soils: Third International Conference on the Biogeochemistry of Trace Elements.

[26] Barnhisel R.I. Correction of physical limitations to reclamation. In: Reclamation of Surface-Mined Lands, Hossner LR (ed.). 1989, CRC Press: Boca Raton, Florida. 1: 191-211. [27] García-Sánchez A., Alonso-Rojo P., Santos-Francés F. Distribution and mobility of arsenic in soils of a mining area (Western Spain). 2010, Sci. Total. Environ. 408: 4194-4201. 
[28] Sebei A. Impacts des rejets miniers sur l'environnement cas des bassins versants des oueds Mellegue et Tessa (Tunisie septentrionale) (In French). 2007, PhD Thesis -Faculty of Science -Tunis (Tunisia). 259p.

[29] Iavazzo P., Adamo P., Boni M., Hillier S., Zampella M.. Mineralogy and chemical forms of lead and zinc in abandoned mine wastes and soils: an example from Morocco. 2012a, J. Geochem. Exploration. 113: 56-67.

[30] Iavazzo P., Ducci D., Adamo P., Trifuoggi M., Migliozzi A., Boni M. Impact of past mining activity on the quality of water and soil in the High Moulouya Valley (Morocco). 2012b, Water. Air. Soil. Poll. 223: 573-589

[31] Bradl H.B. Adsorption of heavy metal ions on soils and soils constituents. 2004, J. Colloid. Interface. Sci. 277: 1-18.

[32] Selim H.M. Competitive Sorption and Transport of Heavy Metals in Soils and Geological Media. 2012, CRC Press.

[33] Sipos P., Németh T., Kovács-Kis V., Mohai I. Sorption of copper, zinc and lead on soil mineral phases. 2008, Chemosphere. 73: 461-469.

[34] Boussen S (2010). Evolution de haldes plombo-zincifères dans le nord de la Tunisie : l'exemple d'un contexte carbonaté (In Frensh). PhD Thesis. 279p.

[35] Tembo B.D., Sichilongo K., Cernak J. Distribution of copper, lead, cadmium and zinc concentrations in soils around Kabwe town in Zambia. 2006, Chemosphere. 63: 497-501.

[36] Ghorbel M., Munoz M., Courjault-Radé P., Destrigneville C., De Parseval P., Souissi R., Souissi F., Ben Mammou A., Abdeljaouad S. Health risk assessment for human exposure by direct ingestion of $\mathrm{Pb}, \mathrm{Cd}, \mathrm{Zn}$ bearing dust in the former miner's village of Jebel RessasNE Tunisia. 2010, Eur. J. Mineral. 22 (5): 639-649.

[37] Rodríguez L., Ruiz E., Alonso-Azcarate J., Rincón J. Heavy metal distribution and chemical speciation in tailings and soils around a $\mathrm{Pb}-\mathrm{Zn}$ mine in Spain. 2009, J. Environ. Manage. 90: 1106-1116.

[38] Wilson-Kokes L., Emerson P., De Long C., Thomas C., Skousen J. Hardwood tree growth after eight years on brown and gray mine soils in West Virginia. 2013, J. Environ. Qual. 42: 1353-62.

[39] Bolland M.D.A., Allen D.G., Barrow N.J. Sorption of phosphorus by soils. 2003, Dept. of Ag. Gov. of Western Australia Bunbury, Western Australia: Dept. of Ag. Gov. of Western Australia.

[40] ICRCL. Guidance on the Assessment and Redevelopment of Contaminated Land. 
Department of the Environment Interdepartmental Committee on the Redevelopment of Contaminated Land. 1987, Guidance Note 59/83: London.

[41] Chakroun H.K. Etude minéralogique et géochimique des rejets miniers du district de Jebel Hallouf-Sidi Bou Aouane: Impact sur le sol et la végétation (In Frensh). 2004, MasterFaculty of Science -Tunis (Tunisia) 90p.

[42] Wong J.W.C., Ip C.M., Wong M.H. Acid-forming capacity of lead-zinc mine tailings and its implications for mine rehabilitation. 1998, Environ. Geochem. Health. 20: 149-155.

How to cite this article:

Sahraoui H. Attia R. Hamrouni H. and Hachicha M.Trace elements lateral distribution and limitations for revegetation in lead mine soils: case of Lakhouat mine, Tunisia. J. Fundam. Appl. Sci., 2016, 8(1), 101-114. 